\title{
Winning in Europe: International Strategies for Hungarian Professional Sports Clubs
}

\author{
Miklós Kozma, Krisztina András
}

\begin{abstract}
A B S T R A C T
Objective: The objective of our research project was to identify key patterns in the international strategies of Hungarian professional sports clubs.

Research Design \& Methods: Initially, two pilot-cases were prepared, which form the basis of additional case studies to be prepared in the later stages of the project. Content analysis was used to systematically assess the transcripts of the interviews, cross-checked with data from sports databases and corporate documentation. Analytical generalisation supports the gradual refinement of research propositions.
\end{abstract}

Findings: Our preliminary results confirmed the relevance of international business theory to be applied in professional sports, also signalling strategic potential in a more conscious pursuit of internationalisation options. A range of strategic patterns of internationalisation were identified.

Implications \& Recommendations: The integration of Hungarian professional sports teams into the international network of sports organisations is likely to intensify, both on the input side (i.e. athletes), and on the output side (i.e. commercial sales) of their operating model. Special strategic patterns focus on the development of new sporting facilities and learning the know-how of commercialisation from international examples.

Contribution \& Value Added: The originality of this work lies in applying the generic internationalisation framework to professional sports in the Central-Eastern European context, as they aim to develop a sustainable operating model through deeper integration into an international network of organisations.

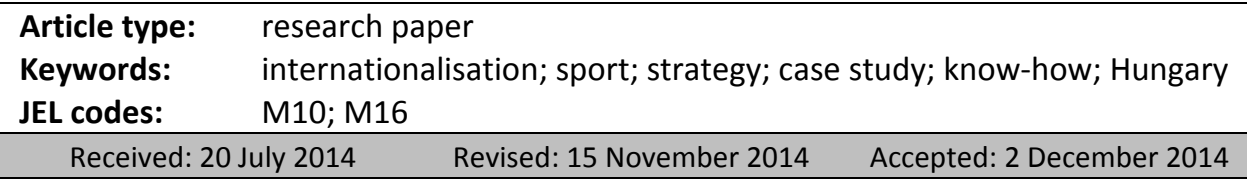

\section{Suggested citation:}

Kozma, M., \& András, K. (2014). Winning in Europe: International Strategies for Hungarian Professional Sports Clubs. Entrepreneurial Business and Economics Review, 2(2), 31-49, DOI: http://dx.doi.org/10.15678/EBER.2014.020403. 


\section{INTRODUCTION}

Sport is embedded in local culture. However, changes in the social and economic fundamentals increasingly create an internationally intertwined flow of operations with far reaching consequences. To many people, sport has become a business. For others, it is still deeply rooted in local culture and commercialisation may only affect the top tier of leagues and competitions. Either way, sport has not stopped to be relevant for governments, businesses and local communities alike, all across the globe. The economics or business of sport is developing into an area of research in its own right.

Chelsea FC, one of the top football clubs in the world, came to Hungary this year to play a pre-season friendly match on the opening day of a brand new stadium. Veszprem, a top Hungarian men handball team has recently announced its plans to join a supranational league in order to play against better opponents. Gyori ETO has won the Champions League the second time in a row to strengthen its position as the best women handball team in Europe. These are a few recent examples that signal how much Hungarian professional sport teams seem to be integrated into an international network of sports organisations.

The objective of our research project was to identify key patterns in the international strategies of Hungarian professional sports clubs. In this paper we present the early results of our project, based on two pilot case studies that can form the basis of a more refined scholarly approach to the consequent stages of our research endeavour.

While sport is embedded in local culture, internationalising operations is an unassailable requirement for professional sports companies' long term sustainability and effectiveness. The theoretical approaches of international business provide rich insights into how global challenges may influence the strategy development of firms in different industries. Professional sports may substantiate another exciting application field for these theories, as sports organisations have idiosyncratic strategies through the inextricably intertwined sporting and commercial goals they pursue. Hence the question arises by what conditions the theories of international business may be applied in this particular field. From a practical point of view, understanding how and why Hungarian professional sports clubs can influence and are influenced by regional and global processes of internationalisation can help us define robust strategies for sustainable success.

\section{LITERATURE REVIEW}

The literature background of our research is twofold: primary theoretical approaches come from the field of international business, especially related to the topic of the internationalisation process through the business network approach; the other major conceptual framework highlights the special characteristics of professional sports as a sector of the entertainment industry, with particular attention to the competitiveness of clubs in professional spectator sports. 


\section{The International Context of Business}

A model of the internationalisation process of companies has been introduced by Johanson-Vahlne (1977). In their empirically based "Uppsala model", the authors emphasise the gradual nature of internationalisation, drafting a typical scheduling of the subsequent steps of companies going international, starting with ad hoc export activity, and concluding with foreign direct investment to control their production abroad. Companies noticeably started their foreign expansion in countries with low "psychic distance" bearing similarities with their domestic market. The "liability of foreignness" was easier to manage in those markets.

Business networks are interpreted by Johanson and Vahlne (2009) as a close and lasting relation between companies and their selected customers or suppliers, typically focused on long term agreements or joint development projects. These international networks are challenging to enter, hindering foreign companies with the "liability of outsidership" if they have no real integration in the network yet.

The motives for the internationalisation of companies can be broken down to two categories: "domestic push" factors that put pressure on firms to expand to foreign markets (e.g. limited market size or restricting government policy), and "international pull" factors that provide attractive opportunities in foreign markets (e.g. lower trade barriers or large international markets) (Czako, 2010).

Another categorisation of the motives for internationalisation (based on Porter, 1980; Yip, 2003) counts with four distinct drivers: (1) government and policy drivers may support the internationalisation of companies; (2) market drivers are substantiated by similar consumer needs across different markets; (3) cost drivers involve economies of scope or scale or build on unique advantages arising from low cost resources; and finally (4) competition drivers relate to tactics between major competitors operating in a similar range of geographies.

The international activities of multinational companies are explained by the eclectic paradigm (Dunning, 2000), which serves as a synthesising framework for theoretical approaches. It claims that multinational firms need to gain advantages in three distinct areas. Firstly, ownership advantages are competitive advantages controlled by the company; hence they can provide a good basis for the potential foreign investments of the firm.

Secondly, location specific advantages arise from countries or regions that attract significant investments of multinational firms. These range from access to valuable resources or favourable government policy to the proximity of complementary industries. Rugman and Verbeke (2001) added the distinction that location specific advantages for a multinational firm can be differentiated between the advantages of the parent country and the receiving country in international business relations.

Finally, internalisation advantages exist where multinational firms can benefit from expanding their organisational coordination to new areas instead of relying on market transactions. If and how these advantages are relevant in case of particular industries or firms vary greatly. Nevertheless, the framework provides a useful analytical tool for assessing internationalisation options. 
The resources and skills that support the international expansion of a firm fall into four basic categories, according to Dunning $(1988,1998,2000)$. These can be sources of competitive advantage, separately or in different combinations, depending on the firm and the markets to target. (1) Market seeking firms focus on additional sales opportunities abroad, (2) efficiency seeking firms are willing to capitalise from economies of scope or scale, (3) strategic asset seeking firms aim to acquire new knowledge through their integration into business networks, while (4) resource seeking firms possess low cost production factors or natural resources.

\section{The Global Context of Professional Sports}

In our interpretation, professional spectator sports have become a sector or the entertainment industry, mainly due to their qualities valuable for the media business (Andras, 2011b). Professional sports clubs are companies providing entertainment services to a diverse range of customers ${ }^{1}$ (Neale, 1964). The global nature of professional sports is reflected in the challenges they face in today's environment. According to Andras (2011a), illustrated by Table 1, the key economic challenges of the current environment of professional sports are the global economic recession and the changing economic systems (Czako, 2012) that provide a framework for business operations in sports (Chikan, 2010).

Table 1. Key environmental challenges to professional sports

\begin{tabular}{|c|c|}
\hline PEST aspects & Key challenges \\
\hline Political & Lowering barriers to international employment \\
\hline Economic & $\begin{array}{l}\text { Global economy as a framework of sport business, economic recession, } \\
\text { changing economic systems, network economy }\end{array}$ \\
\hline Social & Glocalism, XY-generations, information society \\
\hline Technological & $\begin{array}{l}\text { Digital revolution (ICT, mobile technologies, segmentation in the media } \\
\text { market) }\end{array}$ \\
\hline
\end{tabular}

Source: own elaboration based on Andras (2014).

There are sports that are more globally integrated than others. The most apparent common characteristics of these sports are their popularity and attractiveness to the media (Doczi, 2007): football, basketball, ice hockey, Formula-1 etc. However, there are additional drivers of internationalisation in sports. Standardisation is a prevalent aspect of international business (Demeter, 2010). The standardised rules of the game in different sports created monopolistic structures that facilitated the expansion of the sport to new geographies. Another driver is the organisation of events that attract media attention, broadcasting the sport content globally (Dobson \& Goddard, 2004). Recent developments in information technology facilitated the proliferation of broadcasting through non-traditional channels, e.g. via the Internet.

Companies in professional sports are increasingly strategising their international expansion, in an effort to target larger markets (Dobson \& Goddard, 2004). This

\footnotetext{
${ }^{1}$ In this study we exclude the American major leagues from our analysis, due to their fundamentally different approach to business.
} 
expansion is typically achieved through sporting events. If a team representing a nation or a club qualifies for international competition, it enables the companies involved to overcome the limitations of domestic markets. For example, reaching a larger target market may create new opportunities for local or national, but also regional and global sponsorship (Andras, 2004), and a widening range of selling merchandise products (Madeiro, 2007).

The market of player transfers has been international for several decades already. If a professional club enters an international competition, the players are exposed to attention from a wider range of agents and other clubs. The frequency of international transfers increases, especially if efforts in sports diplomacy, strategic cooperation or brand building intensify that impact.

The market of television broadcasting has clearly become global (Andreff, 2008). Major sporting events are broadcasted to $170-220$ countries over the world. This phenomenon is strengthened by the intention of media companies to sell advertising time for higher fees in reflection of the larger audience reached.

The sponsorship market also shows global characteristics, reflected by the business models of the largest sponsors, e.g. Coca Cola, MasterCard, and Adidas. While the legal regulations across different markets are not universally accepted, there is an increasing tendency to identify certain sports, teams, athletes or stadiums with the name of a key sponsor.

In spite of all the global aspects of professional sports operations, "glocalism" is a real challenge. How can companies adapt their services to both the local and the global needs of customers? Supporters often question the values of the increasing number of athletes with double nationality; domestic competitions with record low number of domestic players, and replacing their team stadium's traditional name with that of a multinational firm (Thibault, 2009).

Also, internationalisation in professional sports is understood to be a key driver of the commercialisation of sports (Stewart, 2007; Doczi, 2007). It generated more events, more coverage of competitions, created regional championships, international supporter segments, cooperation agreements between companies in different nations (AndrasJando, 2012), and ultimately changed the traditional nature of how sports are organised.

Recent trends reflect the consequences of globalisation in professional sports in terms of how the business environment changes. International competition intensifies, with a larger number of developing countries joining the global arena, e.g. new locations for Formula-1 races, and Chinese construction companies building stadiums worldwide. Also, national regulations and events are increasingly subject to careful negotiations with the regional headquarters of sport governance bodies. Finally, factor prices tend to level off on a global scale, e.g. the wages of professional players depend less on the strength of the general economy in a given country, as reflected by Hungarian handball clubs signing Scandinavian and Spanish star players. 


\section{Competitiveness in Professional Sports}

Competition plays a key role in how professional sports are organised. In our interpretation, professional sports are characterised by local and broadcast viewers enjoying athletes' performance, paying a fee for this entertainment programme, while athletes receive their income directly or indirectly related to their sporting performance. In this context, the original interpretation of competition in economics - two or more parties trying to gain advantage against each other, keeping to a defined set of rules (Chikan, 1991) - needs to be adapted to the specific nature of professional sports for a range of reasons (Budzinski, 2011). Firstly, sports companies aim to achieve success both from sporting and from business aspects (Kase et al., 2006). Also, cooperation between competitors is not necessarily against the interest of customers; hence monopolistic structures exist in different sport markets. In addition, self-regulatory bodies play important roles in sports in balancing competition (Feddersen \& Maennig, 2005; Krauskopf et al., 2010). Finally, there is strong government intervention in many areas of sports.

Table 2. The interpretation of competition in professional sports

\begin{tabular}{|l|l|l|l|}
\hline \multicolumn{1}{|c|}{ Competition... } & \multicolumn{1}{|c|}{ is for what? } & \multicolumn{1}{c|}{ is against whom? } & \multicolumn{1}{c|}{ occurs where? } \\
\hline $\begin{array}{l}\text { from } \\
\text { sporting aspects }\end{array}$ & sport results & $\begin{array}{l}\text { other participants in the } \\
\text { same competition }\end{array}$ & $\begin{array}{l}\text { in competition } \\
\text { systems }\end{array}$ \\
\hline $\begin{array}{l}\text { from } \\
\text { business aspects }\end{array}$ & $\begin{array}{l}\text { customers' time } \\
\text { and money }\end{array}$ & $\begin{array}{l}\text { other service providers } \\
\text { in the entertainment } \\
\text { industry }\end{array}$ & different markets \\
\hline $\begin{array}{l}\text { from } \\
\text { public value aspects }\end{array}$ & $\begin{array}{l}\text { government } \\
\text { support }\end{array}$ & other sports & $\begin{array}{l}\text { in legislation } \\
\text { decisions }\end{array}$ \\
\hline
\end{tabular}

Source: own elaboration on Andras (2003; 2011b).

It is a fundamental strategic issue in professional sports how sporting success and business success can be simultaneously achieved (Kase et al., 2006; Wilson et al., 2013). As illustrated by Table 2, clubs compete on-field, and also off-the-field, for the time and money of supporters, for the interest of business partners and, based on the public values they generate (Kozma, 2009, 2013; Green \& Collins, 2008), for the support of the different levels of political government (Andras, 2011b).

Competitiveness is a topical issue in economics today (Chikan, 2006). It is normally defined as the ability to sustain in competition for an extended period of time. Competitiveness can be interpreted at four different levels: national, industry, corporate and product level of competitiveness (Chikan, 2006; Czako \& Gaspar, 2007). Other approaches differentiate also regional competitiveness of a larger geographic area (e.g. EU, SE-Asia, Buckley \& Casson, 1998; Mirza, 1998), or a smaller area (Northern Italy, East Anglia, IMD Reports; Porter, 1998). Chikan (2006) underlined that corporate level competitiveness is less clearly defined and measured in economic literature than other levels.

For the purposes of this study, we understand competitiveness as a company's ability to participate in competition with a reasonable chance of success (see more on this by Chikan \& Czako, 2006a). A requirement of competitiveness is the ability to sustain 
operations, as well as to proactively adapt to challenges (Chikan, 2006). In assessing competitiveness, macro- and micro-level, ex ante and ex post, internal and external, input and output-related factors can be differentiated (Nemethne, 2010).

As Figure 1 illustrates, macro-level competitiveness is influenced by government policy. This is all the more so in professional sports, as governments often provide funding and a range of allowances to sports, due to the significant public values sports organisations generate. Regarding micro-level competitiveness, sports companies are increasingly exposed to the effects of global competition, because of the complex internationalisation processes that have so profoundly affected the way professional sports operate.

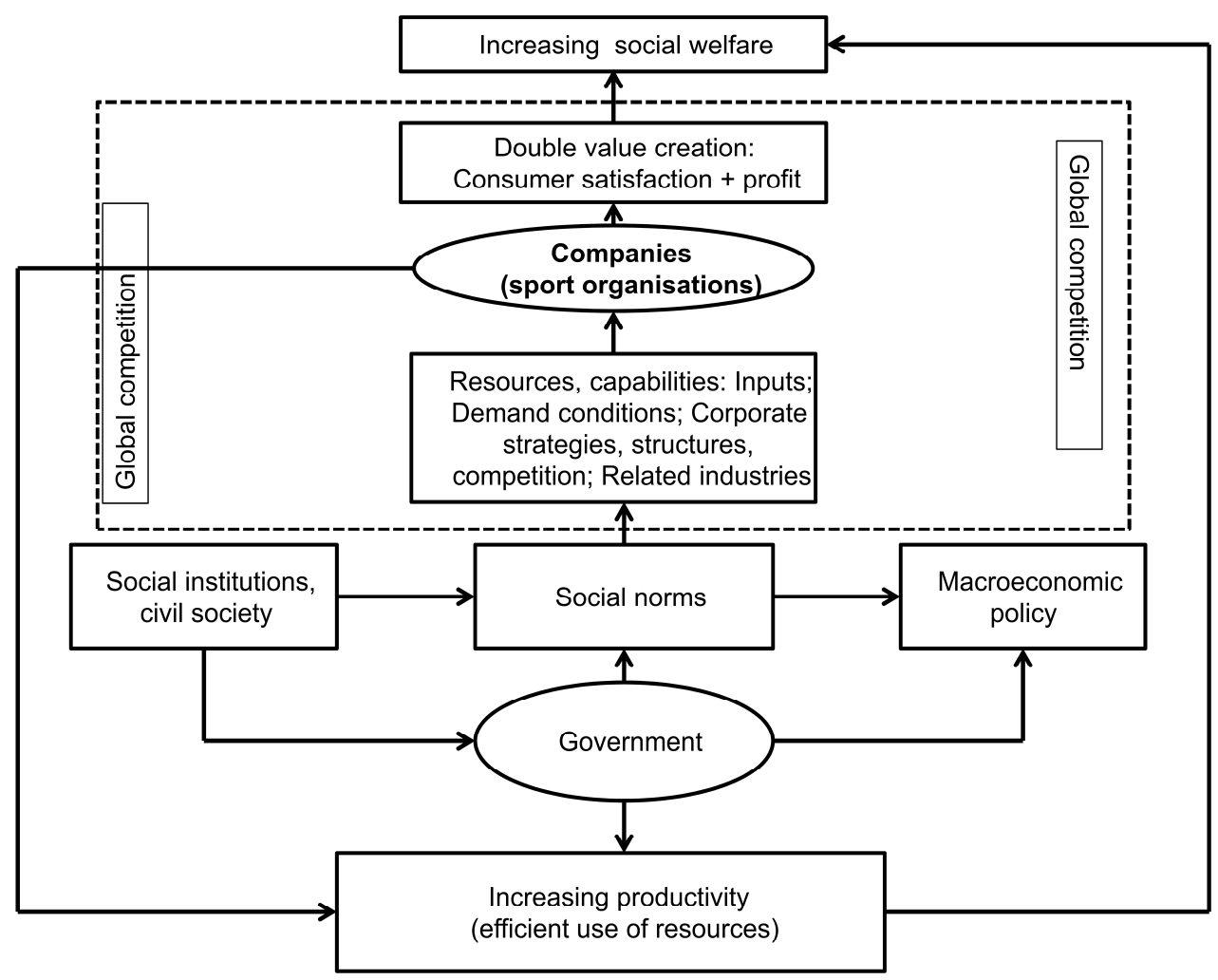

Figure 1. The interrelations between macro- and micro-level competitiveness Source: Chican (2009).

\section{MATERIAL AND METHODS}

Our research approach is based on the interpretative paradigm, using primarily qualitative information. We aimed to apply well tested theoretical concepts in new areas of research, i.e. in professional sports. In this exploratory study we have examined a couple of pilot cases to set the ground for further analytical efforts with an extended number of cases from different sports at varying competitive levels. Our early results 
were expected to provide guidance for the conceptualisation of the subsequent stages of our research project.

Our primary research question focuses on how the management of Hungarian professional sports clubs strategise their integration into the international operations of professional sports. "What patterns can be identified in the international strategies of Hungarian professional sports clubs?" We aim to explore the level of club management's consciousness about their company's integration into a European and global network of sports organisations as an avenue to exploit new market opportunities or improve operational efficiency.

For our research purposes we have applied a conceptual model (Figure 2) to frame our investigation, in order to ensure our efforts are linked to the existing literature of international business and our expected results would be tractable enough for fellow researchers to elaborate upon.

The original propositions were organised around the key focal points of the conceptual model, primarily based on our analytical review of relevant academic articles on international business and the economics of sports. Our understanding of the actual operating conditions of Hungarian professional sports clubs provided further support to refining our original propositions so that they could bear relevance both to future academic endeavours and to potential applications in management practice.

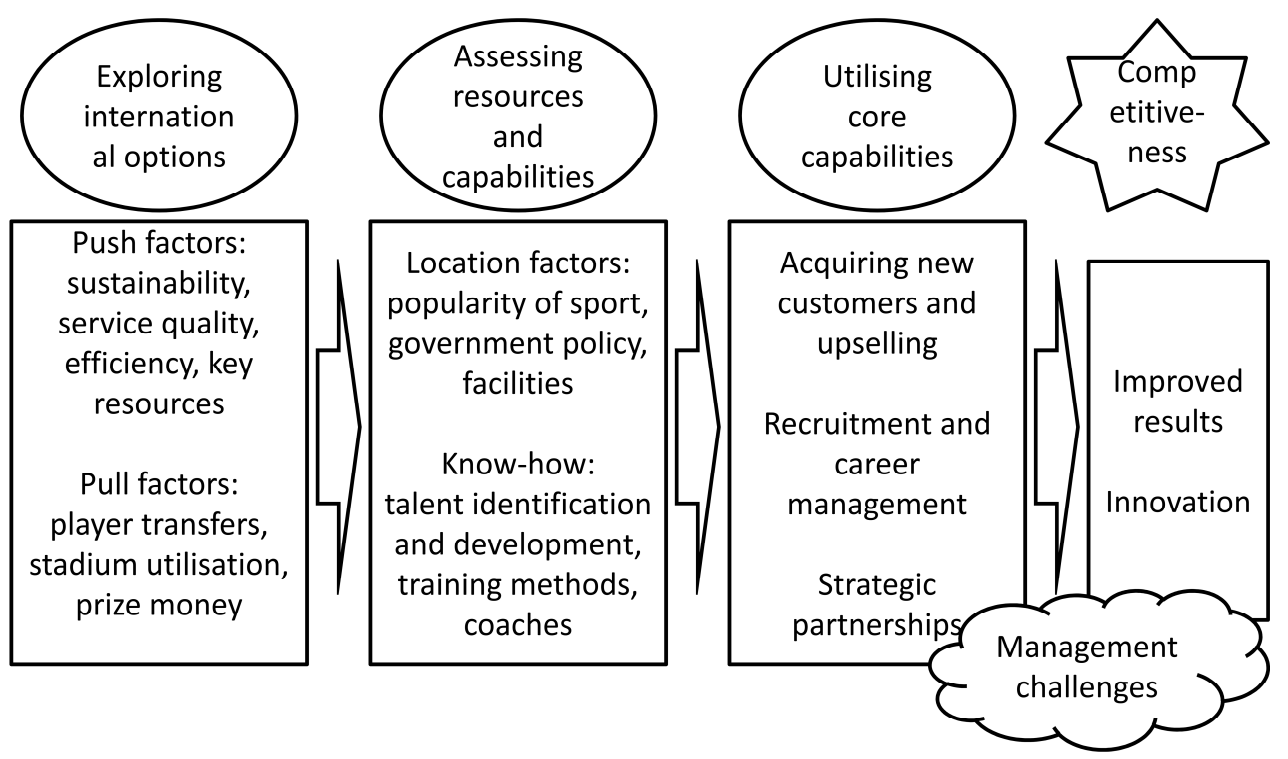

Figure 2. The research model on exploring international strategies

Source: own elaboration based on (Hitt et al., 2007; Czako, 2010).

\section{Research Method}

We selected the case study methodology (Yin, 2003) for our research purposes, as it is in line with the orientation of our research question. As there is no extensive database of information collected about the internationalisation process of Hungarian professional 
sports clubs, and the relevance of the topic is mostly relevant to a limited range of sports clubs, the preparation of a carefully selected list of case studies seemed to be the best choice for our exploratory study.

As the fundamental theoretical models of international business have not been investigated in the field of professional sports clubs yet, we believe that our qualitative findings would serve well to provide a strong basis for more quantitative research projects that may follow. The perceptual nature of key conceptual elements of the theoretical models - e.g. learning, trust, commitment, career options - also necessitated a qualitative approach to understand the conditions in the examined business field.

The case study methodology applied in our project involved conducting in-depth interviews with senior executives of selected professional sports clubs, and crosschecking the collected qualitative data with information from corporate documentation that has also been collected. In order to ensure better reliability of findings, we used the triangulation principle also to check the validity of information (Babbie, 2012).

The topics of our interviews were linked to the key elements of our Research Model, in the following order: motives for internationalisation; evaluating the strategic resources and competences of the professional sports club; utilising the core competences; management challenges in achieving improved competitiveness; room for further innovation to improve results.

In line with the epistemological approach of case study methodology, we did not aim to apply statistical generalisation to a pre-defined population of units of analysis. Instead, we used our findings for analytical generalisation, highlighting where further examination is necessary to expand the scope of relevance to a wider range of empirical cases (Yin, 2003).

In terms of selecting clubs to our pilot sample of two cases, we studied the general qualitative sample selection criteria listed by Miles \& Huberman (1994). Based on the identified options, we selected two of the historically most successful professional clubs of Hungary. Football was a natural choice, because it is the number one sport in Hungary, in terms of popularity, and also because professional football is the most advanced sport in Europe in terms of mass commercialisation. Hence we selected Ferencvarosi TC (FTC) to the sample first. The second sport selected was ice hockey. It is one of the top five spectator sports in Hungary, but with quite a different supporter profile than football. Also, the international competitions in ice hockey are organised differently than in football. Fewer nations support good quality ice hockey leagues; as a consequence, supranational leagues have been established and a number of Hungarian league clubs joined different supranational leagues. Fehervar AV19 (AV19) seemed an easy choice, as it has been the cornerstone of the development of ice hockey in Hungary over a couple of decades, both in terms of sporting development and also from a commercial point of view. Interestingly, AV19 is a country-side club, as opposed to FTC that is the largest club of Hungary operating in the capital city of Budapest. 


\section{The Pilot Sample}

Case \#1: Ferencvarosi TC, Football Club.

Founded in 1899, FTC is the historically most successful football club in Hungary. They are 28 times champions, 20 times Cup winners. Their first international success occurred in 1928 when they won the Central-European Cup. They repeated this feat in 1937, and other significant European cups in 1965 and 1975. In 1995, they entered the group stage of the European Champions League as the first Hungarian team ever.

FTC has the largest base of supporters in Hungary, estimated to be over 300000 fans, with passive followers amounting to over 1 million. However, even FTC could not bring to their matches more than 6-8 thousand supporters on average.

The government recently built a state-of-the-art new stadium for the club, with a capacity of over 22000 seats. The management of the new stadium has been contracted out to an internationally reputable facility management company.

The financially most advanced football league in the world is the English Premier League, including professional clubs from England and Wales. The total revenues of the largest English club exceed EUR 400 million, compared to FTC's budget of below EUR 6 million.

Case \#2: Fehervar AV19, Ice Hockey Club.

Founded in 1960, Fehervar AV19 (AV19) is one of the historically most successful ice hockey clubs in Hungary. They are 13 times champions, five times Cup winners. They were the first country-side club that could win the championship, breaking the dominance of Budapest club Ferencvaros.

They made a great step in internationalisation, when they joined Interliga, a supranational competition in 1997. Based on their international reputation and good relationship with a number of foreign clubs, they were invited to the more prestigious Erste Bank Eishockey Liga (EBEL) in 2007, where they could play against superior Austrian, Slovenian, Croatian, Czech and Italian clubs. They do not show consistently good performance in EBEL, being the club with the lowest budget in the league, but occasionally they surprisingly beat even their best opponents.

They use a local municipality-owned hall of 3500 seats capacity, built in 1977, which they normally sell out for league games. They also sell out their VIP seats (app. 150 seats) for an increasing level of price every year. There are plans for a new 5000-seat hall to be built by the government in the next few years.

The top league in the world is the North-American National Hockey League, including professional clubs from the USA and Canada. The total revenues of the best Canadian clubs are over EUR 110 million, compared to AV19's budget of just over EUR 1 million.

\section{Limitations of Methodology}

In our understanding, the quality of a research methodology lies in the harmony between the research question, the data collected and the analytical methods. We did our best to adjust our methodology to the limited availability of quantitative data, and the newness of the research question as identified through our literature review. 
However, there are limitations to how our early results can be processed for further research, due to the following issues.

Firstly, sports are usually strongly embedded into the local culture and social relationships; hence any attempt to generalise findings for the purpose of economic analysis may oversimplify the idiosyncratic nature of club operations. Furthermore, key concepts of the theoretical literature of international business are not familiar to most of the professional club managers, even to the commercially skilled ones. Our efforts to translate the conceptual elements to practical terms may raise issues of validity and reliability. Finally, there is a chronic lack of reliable quantitative data about the business of sports in Hungary, due to a traditional non-business approach to managing sports organisations. Our intention to cross-check interview information with factual written information was sometimes severely compromised by the availability of such information.

\section{PRELIMINARY RESULTS}

Based on the answers from our interviewees and the analysis of related documentation, we have been able to refine our understanding of the strategic approach the selected Hungarian professional clubs developed. While the immediate generalisability of our findings is limited, they can serve as a basis for the subsequent stages of our research.

In this section we explain our propositions that we plan to use in the case studies that we have scheduled in for the coming months. Also, we provide explanation of the strategic patterns identified in how the examined professional sports clubs approached the opportunity and the challenge of internationalisation.

Proposition 1: While push factors dominate the motives for the internationalisation of professional sports clubs in Hungary, pull factors are gaining relevance.

Both of the examined cases highlighted that the primary motive for setting sights on international competition is a need for improving sporting performance, which has been confirmed as the fundamental strategic orientation of professional clubs. As both clubs in the sample have a tradition of regularly winning their respective domestic championships, if they aim to please their supporters there is no real alternative to entering international competitions and achieving results beyond immediate expectations. This is the requirement of satisfying the profound needs of their domestic fans.

The process of internationalisation along this line of thought follows an interesting pattern, shown by Figure 3. The primary motive was a push factor, i.e. the need to satisfy domestic supporters by improving sporting performance. This strategic goal implied a parallel goal which was the construction of a new stadium, as without a high quality facility supporters were understood to lose interest in attending matches anyway. The challenge of operating the new stadium in a sustainable way called for learning from foreign clubs, in pursuit of new revenue generation opportunities that could provide the financing required to cover the increased operating expenses of the club. After all, the stadium is understood to be a key tool for revenue generation for modern, commercially managed football clubs (Kozma \& Kazaine, 2013, 2014). 


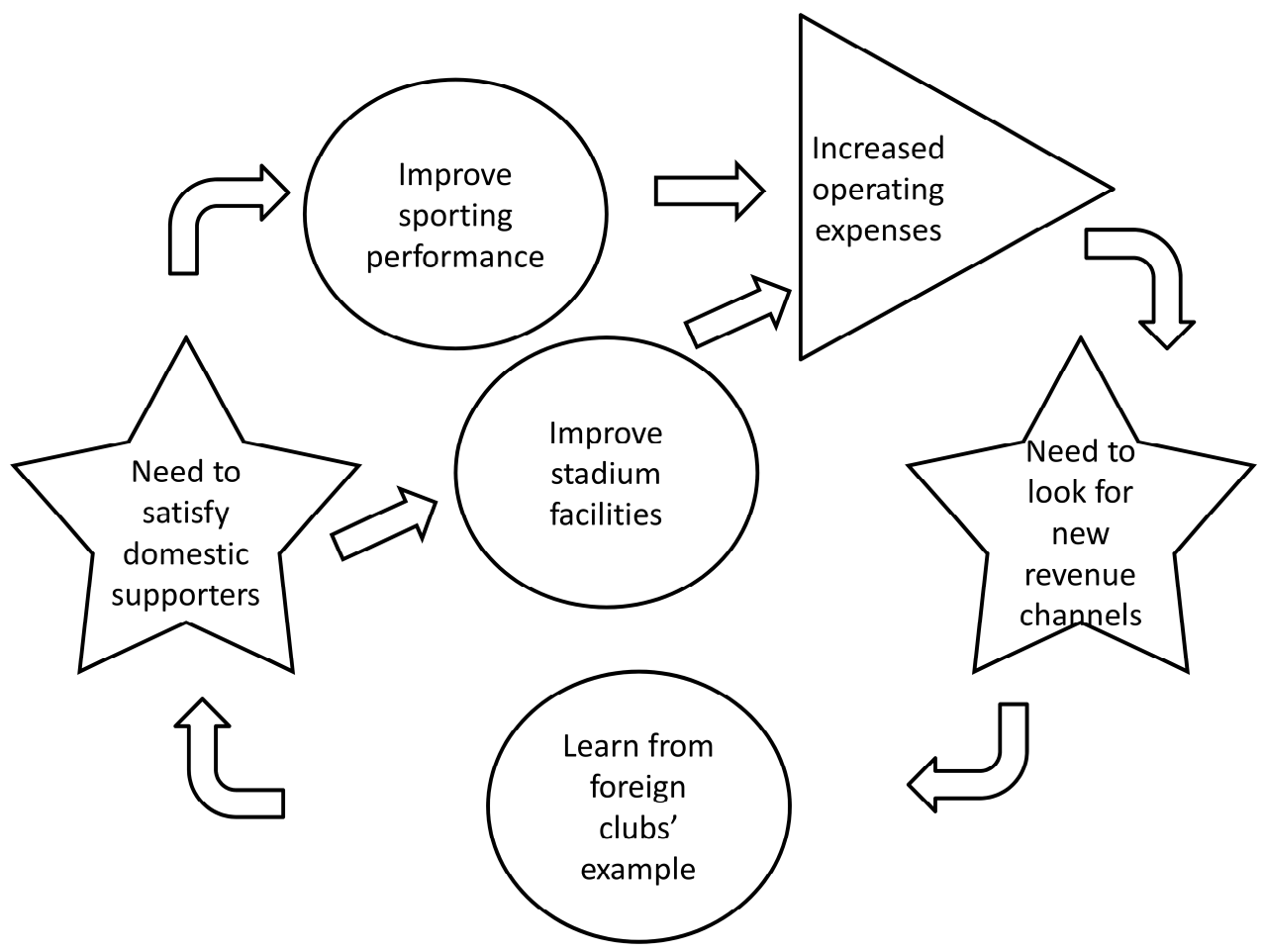

Figure 3. Simplified strategic pattern for internationalisation for FTC football club Source: own elaboration.

The case of AV19 ice hockey club appears to confirm the identified pattern. As a leading Hungarian club, they play in an international league (EBEL) in order to bring exciting matches to their domestic supporters. In an effort to establish a sustainable future for the club, they plan to upgrade their facility to a larger and better quality hockey arena, from government funds. Whether they will be able to identify new customer segments or benefit from up-selling opportunities is yet to be seen. They certainly do not have an explicit business plan on how to exploit the new options, and may look for examples abroad to understand how more revenues could be generated.

Proposition 2: The key push factors are the need for improved sporting performance and the consequent pressure for establishing financial sustainability.

Our understanding from the case studies is that the usual "play better and pay better" phenomenon prevails in Hungary, but it also acts as a catalyst for internationalisation (Szymanski \& Kuypers, 1999). There is a distinct flow of logic that we could identify through our interviews and the analysis of related documentation (Figure 4).

Two parallel processes intensify the pressure on Hungarian professional sports clubs to improve their sporting performance. First, there is a general proliferation of entertainment opportunities through a greater than ever array of electronic platforms and devices. The entertainment tools provide are more visual, more action oriented and 
more exciting than any substitute products professional spectator sports had to face before. Also, in relation to the improvement of technological opportunities, there is more depth and breadth of the coverage of top sport matches played in the highest level leagues all around the globe. Both of these trends put pressure on Hungarian professional sports clubs to improve their quality of play and the experience they can offer to their supporters.

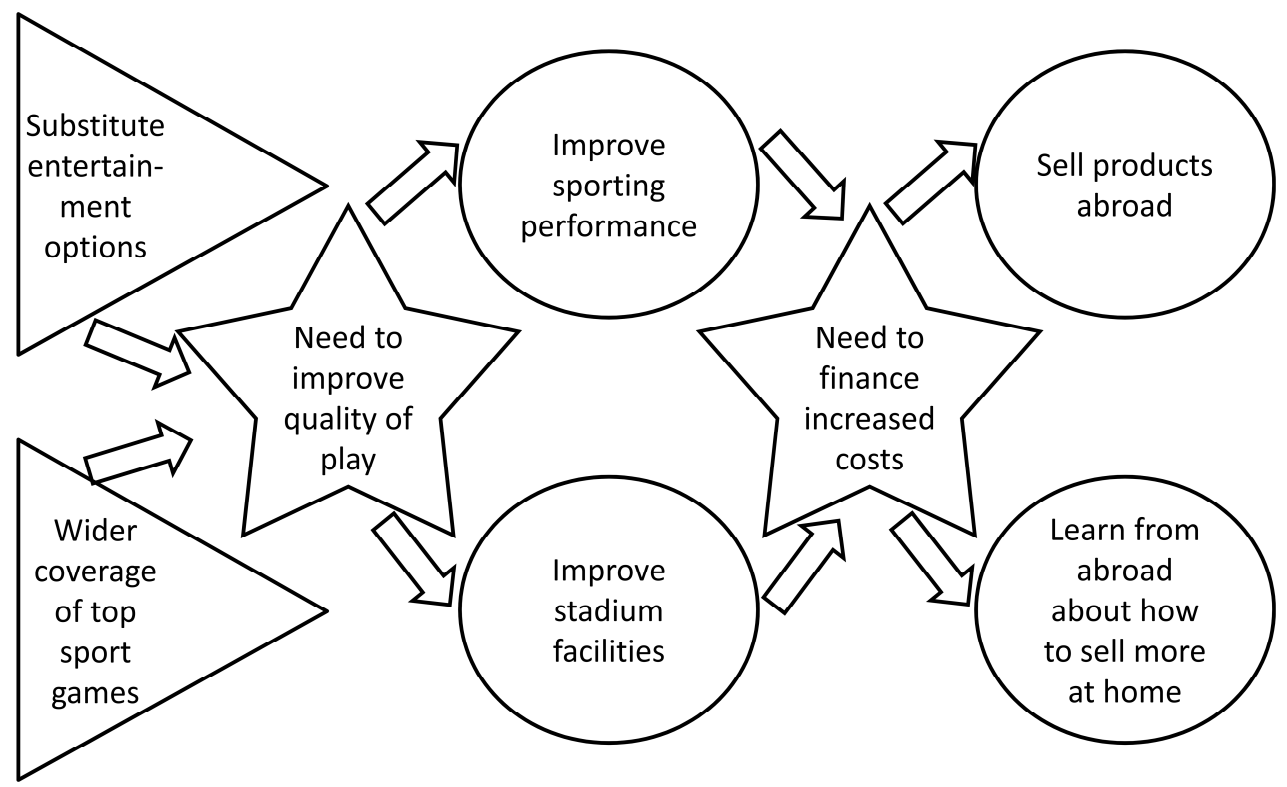

Figure 4. A refined pattern of how push factors lead to increasing internationalisation Source: own elaboration.

Hungarian professional sports clubs have two major avenues for progressively responding to the financing pressure. First, they aim to sell their products abroad, in larger markets that provide new revenue generating opportunities of almost incomparably larger measure (Kozma \& Nagy, 2003). For example, income from playing in the group stage of the European Champions League of football, even if the team fails to win a single match, normally involves additional prize income from the competition that can double the total revenues the club manage to achieve in a year without playing in the Champions League. This way, the sporting performance of the Hungarian club becomes a part of an international product that the European football association (UEFA) can sell to a much larger market to the benefit of all clubs participating.

The other opportunity to positively respond to the pressure is learning from foreign clubs how to gain more revenues from the available domestic market. The size of the domestic market in Hungary is in fact smaller than that of clubs operating in a more sophisticated commercial environment (e.g. Germany and the UK in football, and Scandinavia in ice hockey), but the know-how of utilising revenue generating opportunities from a new facility is still worth to learn. Internationalisation by learning 
the best practice in other markets is a powerful strategic opportunity for clubs in Hungary.

Proposition 3. Recent improvements in location factors mitigate the strategic disadvantage of Hungarian professional sports clubs in international markets.

In order to boost the sporting performance of a range of sports, the Hungarian government decided to provide direct funds for the development of a range of state-ofthe-art sporting facilities, and indirect funds to support youth development and to an extent also the smooth operations of professional clubs. All of these efforts were meant to close the gap in the competitiveness between Hungarian sports and sports in larger markets.

Youth development and facility upgrades are two strategic areas which are understood to have the potential for supporting the sustainable sporting performance of clubs. Our interviews confirmed that the management of clubs understand this opportunity and aim to build on it.

The two examined cases showed different perspectives of how professional sports clubs could actually benefit from the supportive government programmes. Other location factors affect the two clubs differently. Football has a very large supporter base, though most of them are inactive. Also, Hungary boasts a proud tradition of the "Golden Team" of the 1950s which was almost unbeatable on international scenes at the time. Also, there are clubs with great tradition, a few of which operate, even today, with relatively stable financial background, so that they can provide challenging competition to each other in the domestic league (most notably FTC, DVSC and Videoton). If FTC will enter a European competition and have a good run in the first few rounds, the commercialisation opportunities will be very substantial. With careful management, the extra income could be reinvested into both the playing squad and the development of additional commercialisation solutions.

In case of AV19, such international playing success would not bring a comparable surge in income, and the domestic commercialisation potential is also lower due to the smaller fan base of ice hockey in Hungary. However, they could benefit from applying the best practice of international commercialisation know-how, as their fan base has a higher per capita spending power than that of FTC. This is also confirmed by the fact that, according to clubs statistics, many supporters (over $40 \%$ ) travel from other cities, even from Budapest over $60 \mathrm{~km}$ away, to see the matches of this country-side club.

Overall, the location factors of professional sports clubs in Hungary have improved, but cannot provide a basis for sustainable competitive advantage without new club strategies adjusted to taking advantage of the internationalisation options.

Proposition 4. The internationally linked career management of professional players is one of the core competences of strategically successful Hungarian sports clubs.

Analysis of the two cases appears to support this proposition, though from different perspectives. In this regard, AV19 is in a more advanced position than FTC. More than 15 years ago, the club started to employ foreign head coaches to the professional team. First Russians, than Slovakians came, while Pat Cortina arrived in 2004, starting a succession of Canadian coaches with little interruption. Naturally, foreign coaches opted for contracting foreign players, apart from relying on the talent 
coming through the ranks of the club's grass-roots programme. The gradual inflow of quality foreign players helped the coaches to fill the gaps in the roster, where local talent was not available in the required quality. The consequence was a series of sporting success, which also led to the club's involvement in a higher-level regional league (EBEL), including mostly top-tier Austrian and Slovenian ice hockey clubs. More visibility in a higher-level league further improved the attractiveness of playing for AV19 in the eyes of an increasingly wider pool of foreign talent. Our interviews confirmed that the club may serve as a stepping stone in the career of young foreign players so that later they can sign for a top international club, based on the experience gained at AV19. Figure 5 illustrates this strategic pattern.

Our findings from the case of FTC are in line with the pattern identified at AV19, but they have not managed to apply this pattern with equal success yet. Hitherto, there has not been a succession of foreign coaches from a top European football nation at FTC, and the international career paths of FTC's players do not seem to show a consistent pattern. However, it is the intention of current management to benefit from the opportunity to get integrated into the international player career network, both because this is expected to attract more talent to the club, and because there is a potential revenue source from quality players signing to top clubs from FTC. A most recent element of the implementation of this international strategy is the signing of Bosnian Muhamed Besic to a top-tier European club, following its successful years of playing for FTC and also showing his talent at FIFA World Cup 2014.

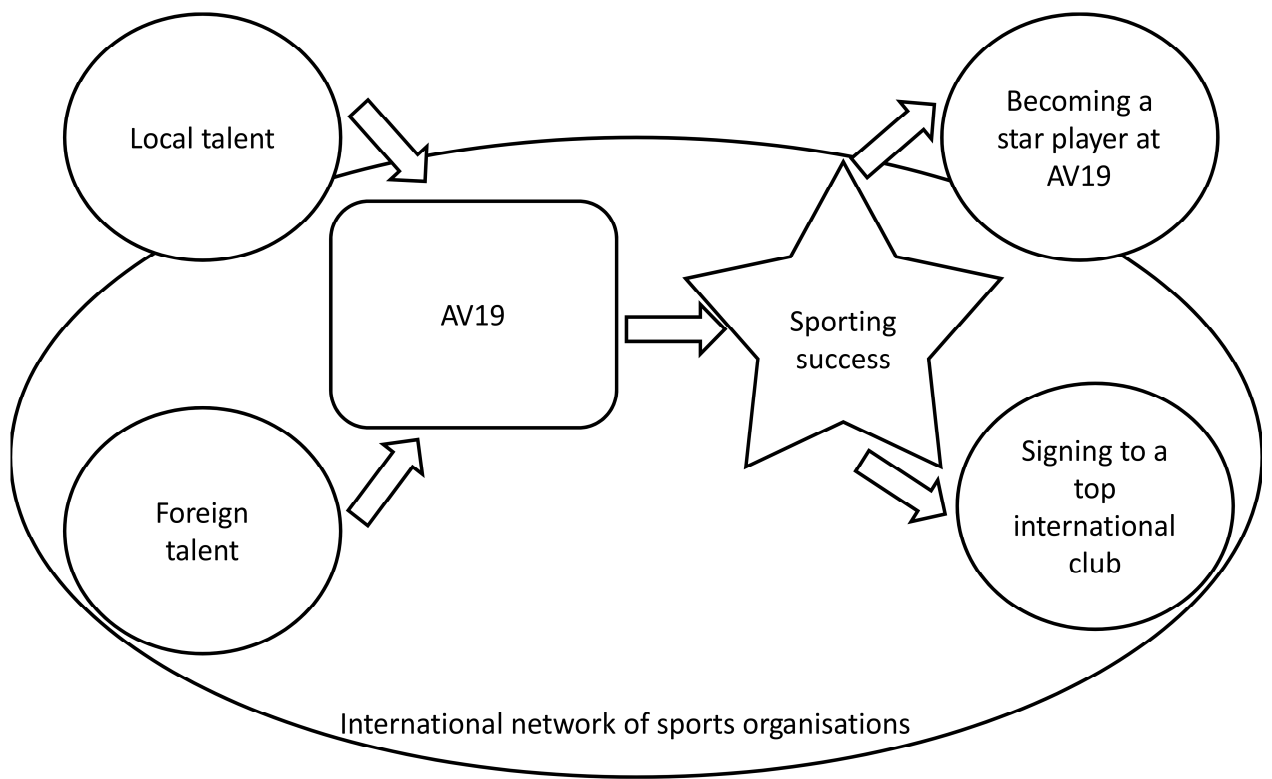

Figure 5. Identified pattern of integration into international player careers Source: own elaboration.

Proposition 5. Strategic partnerships can become key opportunities for strategic breakthrough for professional sports clubs in Hungary. 
Both clubs in our sample provided a case for supporting Proposition 5, although in a refined format. FTC leads the way in Hungarian football, in terms of contracting an internationally reputable stadium operator to manage the newly built facility. The rationale behind the agreement is that no operators in Hungary have the international experience that is supposed to be required for utilising stadium capacities outside the needs of the professional team. What content can be attracted to the facility and how this can be achieved is part of the know-how FTC is willing to import to the country.

The case of AV19 can also be interpreted as a story of strategic partnerships and learning. Though the contractual relationship between the club and its succession of foreign coaches was different than that between companies, this long-term relationship channelled international know-how of player management and also club operations to Hungarian ice hockey.

\section{CONCLUSIONS}

Our pilot case studies have confirmed the relevance of international business theory to be applied in professional sports and lead to promising conclusions. Firstly, the importance of international pull factors is on the rise, signalling strategic potential in a more conscious pursuit of internationalisation options. Secondly, the integration of Hungarian professional sports teams into the international network of sports organisations is likely to intensify, not only on the input side (i.e. athletes), but also on the output side (i.e. commercial sales) of their operating model. Thirdly, the global competition challenge Hungarian professional sports clubs face is expected to stimulate the development of special strategic patterns that may add depth to the general internationalisation models based on empirical findings of more developed nations. Early results drafted such patterns focused around the development of new sporting facilities and the need to learn the know-how of commercialisation from international examples. These patterns are to be further refined through additional case studies to provide the basis of more powerful analytical generalisation. Finally, the motives for intensifying internationalisation are deeply rooted in the economic structure of professional sports; hence this area of research is expected to remain in the interest of academics and business practitioners for many years to come.

\section{REFERENCES}

Andras, K. (2003). Uzleti elemek a sportban. Ph.D. ertekezes, Budapesti Kozgazdasagtudomanyi es Allamigazgatasi Egyetem.

Andras, K. (2004). A hivatasos labdarugas piacai. Vezetestudomany. XXXV. evfolyam, PhD kulonszam 40-57.

Andras, K. (2011a). Piacmeretet novelni, de hogyan? - a hivatasos sport peldajan. NSSz Sportszakember tovabbkepzesi konferencia sorozat. III. 27-32.

Andras, K. (2011b). A hivatasos labdarugas mukodesi modellje. Sportagak versenye - MSTT fuzetek. III. 18-42.

Andras, K., \& Jando, Z. (2012). Hivatasos sportvallalatok nemzetkozive valasa. Logisztikai hirado, 3, 42-47. 
Andreff, W. (2008). Globalization of the sport economy. Rivista di diritto ed economia dello sport. Fasc. 3.

Babbie, E.R. (2012). The practice of social research. Wadsworth: Cengage Learning.

Buckley, P. J. (2009). Internationalisation thinking: from the multinational enterprise to the global factory. International Business Review, 18, 224-235.

Buckley, P.J., \& Casson, M. (1998). Models of the multinational enterprise. Journal of International Business Studies, 29, 21-44.

Budzinski, O. (2011). The institutional framework for doing sports business: Principles of EU competition policy in sports markets. Working Paper, Department of Environmental and Business Economics, University of Southern Denmark, No. 108

Chikan, A. (1991). Vallalatgazdasagtan. Budapest: AULA Kiado.

Chikan, A. (2006). A vallalati versenykepesseg merese. Penzugyi Szemle, 1, 42-57.

Chikan, A. (2009). A kozgazdasagtudomany es a magyar sport - egy elemzesi keret c. eloadasa. Sporttudomanyi konferencia. MTA, Budapest 2009. oktober 9.

Chikán, A. (2010). A globalis gazdasag - az uzleti tevekenyseg kerete. In: E. Czako, L. Reszegi (Eds.), Nemzetkozi vallalatgazdasagtan. Budapest: Alinea Kiado.

Chikan, A. \& Czako, E. (2006a). A versenykepesseg szintjei: fogalmak es ertelmezesek, Versenykepessegi Kutatasok muhelytanulmany-sorozat, Versenykepesseg Kutato Kozpont, Budapest.

Chikan, A., \& Czako, E. (Eds.). (2006b). Versenyben a vilaggal, - vallalataink versenykepessege az uj evezred kuszoben. Budapest: Akademia Kiado.

Czako, E., \& Gaspar, J. (2007). Vallalatok nemzetkozive valasa es a versenykepesseg. In: M. BartekLesi, I. Bartok, E. Czako, J. Gaspar, E. Konczol, \& E. Pecze (Eds.), Vallalati Strategia. Budapest: Alinea Kiado.

Czako, E. (2010). A nemzetkozi strategia teruletei. In: E. Czako, \& L. Reszegi (Eds.). Nemzetkozi vallalatgazdasagtan. Budapest: Alinea Kiado.

Czako, E. (2012). A nemzetkozi kornyezet elemzese. Lecture on International Business, Corvinus University of Budapest, 29 February 2012.

Demeter, K. (2010). A termeles es szolgaltatasnyujtas. In: E. Czako, \& L. Reszegi (Eds.). Nemzetkozi vallalatgazdasagtan. Budapest: Alinea Kiado.

Dobson, S., \& Goddard, J. (2004). The economics of football. Cambridge: Cambridge University Press.

Doczi, T. (2007). Sport es globalizacio: a XXI. szazad kihivasai. Kalokagathia, 1-2, 5-13.

Dunning, J.H. (1988). The eclectic paradigm of international production: A restatement and some possible extension. Journal of International Business Studies, 19, 1-31.

Dunning, J.H. (1998). Location and the multinational enterprise. A neglected factor? Journal of International Business Studies, 1, 45-66.

Dunning, J.H. (2000). The eclectic paradigm as an envelope for economic and business theories of MNE activity. International Business Review, 9, 163-190.

Feddersen, A., \& Maennig, W. (2005). Trends in competitive balance: is there evidence for growing imbalance in professional sport leagues? Hamburg Contemporary Economic Discussions, 1, 113.

Green, M., \& Collins, S. (2008). Policy, politics and path dependency: sport development in Australia and Finland. Sport Management Review, 11, 225-251. 
Hitt, M.A., Hoskisson, R.E., \& Ireland, D.R. (2007). Management of Strategy. Concepts and Cases. International Student Edition. Thomson-South Western.

Johanson, J., \& Vahlne, J.E. (1977). The internationalization process of the firm: a model of knowledge development and increasing foreign market commitments. Journal of International Business Studies, 8, 12-32.

Johanson, J., \& Vahlne, J.E. (2009). The Uppsala internationalization process model revisited. From liability of foreignness to liability of outsidership. Journal of International Business Studies, 9 , 1411-1431.

Kase, K., Gomez, S., Urrutia, I., Opazo, M., \& Marti, C. (2006). Real Madrid - Barcelona: business strategy vs. sports strategy, 2000-2006. Occasional Paper. OP no. 06/12-E. IESE Business School. University of Navarra.

Kozma, M., \& Nagy, T. (2003). Nagy penz - kis foci, avagy a paradigmavaltas lehetosege a magyar labdarugasban, Vezetestudomany, 6.

Kozma, M. (2009). Ertekteremtes Public-Private Partnership kereteben - kulonos tekintettel a vallalkozo szempontjaira. Ph.D. ertekezes, Budapesti Corvinus Egyetem

Kozma, M. (2013). Public-Private Partnership Magyarorszagon - egy felreertes volt?, Vezetestudomany, 2, 20-27.

Kozma, M., \& Kazaine, O.A. (2013). Measuring Business Performance in Sports, How the Balanced ScoreCard approach can help sports organisations in operating along strategic objectives, Proceedings of International Conference on Economics and Business Management, Cluj Napoca, Romania, 23 November 2013.

Kozma, M., \& Kazaine, O.A. (2014). Measuring Business Performance in Sports, How revenue and cost calculations can help sports organisations in making good business management decisions, Proceedings of IRI Economics Conference, Komarno, Slovakia, 20-22. January 2014.

Krauskopf, T., Langen, M., \& Bunger, B. (2010). The search for optimal competitive balance in Formula-1. Discussion Paper No. 38. Center for Applied Economic Research Munster.

Madeiro, G. (2007). Sport and power: globalization and merchandizing in the soccer world. Society and Business Review, 3, 287-298.

Miles, M.B. - Huberman, A.M. (1994). Qualitative Data Analysis. London: Sage.

Mirza, H. (1998). Global Competitive Strategies in the New World Economy, Cheltenham: Edward Elgar.

Neale, W.C. (1964). The peculiar economics of professional sports. Quarterly Journal of Economics, 78, 1-14.

Nemethne, G.A. (2010). A kis- es kozepvallalatok versenykepessege - egy lehetseges elemzesi keretrendszer. Kozgazdasagi Szemle, LVII. evf., 181-193.

Porter, M.E. (1980). Versenystrategia, Budapest: Akademiai Kiado.

Porter, M.E. (1990). Competitive Advantage of Nations, New York: The Free Press.

Porter, M.E. (1998). On Competition, Boston: Harvard Business School Press.

Rugman, A.M., \& Verbeke, A. (2001). Subsidiary-specific advantages in multinational enterprises. Strategic Management Journal, 3, 237-250.

Stewart, B. (2007). Sport Funding and Finance. Oxford: Elsevier.

Szymanski, S., \& Kuypers, T. (1999). Winners \& Losers - The Business Strategy of Football, London: Viking. 
Thibault, L. (2009). Globalization of sport: an inconvenient truth. Journal of Sport Management, 23, 1-20.

Wilson, R., Plumley, D., \& Ramchandani, G. (2013). The relationship between ownership structure and club performance in the English Premier League. Sport, Business and Management: An International Journal, 1, 19-36.

Yin, R. K. (2003). Case Study Research - Design and Methods; California, Thousand Oaks: SAGE Publications.

Yip, G. (2003). Total Global Strategy. London: Prentice Hall.

\title{
Authors
}

The contribution of the authors is as follows:

Miklós Kozma - 60\%, Krisztina András - 40\%.

\section{Miklós Kozma}

Senior Assistant Professor at the Sports Business Research Centre, Faculty of Business Administration, Corvinus University of Budapest. PhD in Business Administration by Corvinus University of Budapest (Hungary).

\section{Krisztina András}

Senior Assistant Professor at the Sports Business Research Centre, Faculty of Business Administration, Corvinus University of Budapest. PhD in Business Administration by Corvinus University of Budapest (Hungary).

\author{
Correspondence to: \\ Miklós Kozma, PhD \\ Corvinus University of Budapest \\ Faculty of Business Administration \\ Fovam ter 8 \\ $\mathrm{H}-1093$ Budapest, Hungary \\ miklos.kozma@uni-corvinus.hu
}

\section{Acknowledgements and Financial Disclosure}

We thank Dorottya Gerics and Gabor Baranya, students of the Corvinus University of Budapest, for their unyielding assistance to our work.

\section{Copyright and License}

This article is published under the terms of the Creative Commons Attribution - NonCommercial - NoDerivs (CC BY-NC-ND 3.0) License http://creativecommons.org/licenses/by-nc-nd/3.0/ 
